\title{
Power and control: managing agents for international student recruitment in higher education
}

Article

Accepted Version

Huang, I. Y., Raimo, V. and Humfrey, C. (2016) Power and control: managing agents for international student recruitment in higher education. Studies in Higher Education, 41 (8). pp. 1333-1354. ISSN 0307-5079 doi:

https://doi.org/10.1080/03075079.2014.968543 Available at https://centaur.reading.ac.uk/37976/

It is advisable to refer to the publisher's version if you intend to cite from the work. See Guidance on citing.

Published version at: http://dx.doi.org/10.1080/03075079.2014.968543

To link to this article DOI: http://dx.doi.org/10.1080/03075079.2014.968543

Publisher: Taylor \& Francis

All outputs in CentAUR are protected by Intellectual Property Rights law, including copyright law. Copyright and IPR is retained by the creators or other copyright holders. Terms and conditions for use of this material are defined in the End User Agreement.

www.reading.ac.uk/centaur 
Central Archive at the University of Reading

Reading's research outputs online 


\title{
Power and control: Managing agents for international student recruitment in higher education
}

\author{
Iona Yuelu Huang ${ }^{* a}$, Vincenzo Raimo ${ }^{\mathrm{b}}$ and Christine Humfrey ${ }^{\mathrm{c}}$
}

This multiple case-based study investigates the relationship between recruiting agents and the UK universities who act as their principals. The current extensive use of agents in UK higher education may be seen as an indicator of the financial impact made by international students. The study analyses the practice of agent management and explores the manner in which power and control interact. The study employed semi structured interviews and group discussions involving up to six respondents from each of the twenty UK case institutions. The qualitative data reveal a considerable variation in the manner in which the universities manage their agency relationships. Through the joint consideration of control measures and use of power, five distinctive approaches have been identified. The study also reveals that over-dependence on agents reduces the power of the principal, and consequently the principal's ability to exercise control, particularly in highly competitive global and national markets.

Keywords: education marketing; international recruitment agents; power and control; agency theory

*a Corresponding author. Land and Agri-Business Management Department, Harper Adams University, Newport, Shropshire, TF10 8NB, UK. Email: ihuang@harperadams.ac.uk. Tel: +44 1952815156.

${ }^{\mathrm{b}}$ Vice-Chancellor's Office, University of Reading, Whiteknights, Reading, Berkshire, RG6 6AH, United Kingdom. Email: v.raimo@reading.ac.uk; Tel: +44 1183787102.

${ }^{\mathrm{C}}$ The University of Nottingham, Jubilee Campus, Wollaton Road, Nottingham NG8 1BB, UK. Email:c.humfry@btinternet.com. Tel: +441159253841. 


\section{Introduction}

International higher education has moved towards marketisation (Ek et al. 2013) and commodification (Woodall, Hiller and Resnick 2014) over the past forty years. The UK Government's Industrial Strategy for International Education (BIS 2013) estimates that education exports were worth $£ 17.5$ bn to the UK economy in 2011. By far the largest contributor to this are the almost 500,000 non-UK domiciled students studying on undergraduate and postgraduate degree programmes in UK universities. About two thirds of this number come from outside the EU, and so are subject to the payment of overseas tuition fees. In 2012-13, 12.1 per cent of the income of all UK universities came from international students, although some universities have a greater dependency (up to 41.1 percent) on this source of income than others (HESA 2014).

Competition is keen and likely to become more so as additional countries such as China and Malaysia progress from consumers to providers of international higher education. A global recession which, in the UK, is particularly affecting public sector spending, has led to constraints in university budgets and thus to a need to sustain or even expand the numbers of non-EU students bringing fee income to the institutions. The efforts and successes of UK universities have to be increased or refined to meet student intake targets in a competitive market, and the optimal use of agents is one of the ways in which this might be achieved. It has been reported that more than $100 \mathrm{UK}$ Higher Education Institutions (HEIs) used international student recruitment agents in 2012 and in the academic year 2010/11 50,000 international students were recruited through agents, with total commission payments of $557.8 \mathrm{~m}$ (Matthews 2012).

The value of international education is seen as more than the financial contribution made by fees. Its contribution in academic, cultural and diplomatic terms is understood. Throughout the paper the interpretation of 'agent' and 'principal' and the 
issues involved in this relationship, are considered through the lens of this multidimensional contribution. The benefits and the risks of agent engagement are heightened in this special environment.

As with any principal-agent relationship, the use of international recruitment agents can be resource demanding and potentially cause damage to the university's reputation (Inderst and Ottaviani 2009; Brabner and Galbraith 2013). Although there has been some debate on the risks associated with using agents (Reisberg and Altbach 2011; Raimo 2013), there seems to be little understanding of the governance and control of this channel of recruitment by both academics and practitioners.

The purpose of this research is to investigate how the agency relationship is managed. While conscious of the special nature of international higher education, the underpinning assumption of this paper is that the relationship between universities and their international recruitment agents is that of a typical principal-agent relationship. The contractual relationship between the parties is also a social exchange where power asymmetry is a natural phenomenon (Yen, Yang and Cappellini 2012).

There is a large body of work on power (Emerson 1962; Hunt and Nevin 1974; Frazier and Summers 1984; Gaski 1986; Kumar 2005; Meehan and Wright 2012) and principal-agency relationships (Eisenhardt 1989; Sharma 1997; Quinn and Doherty 2000; Merritt and Newell 2001; Tate et al. 2010; Zu and Hale 2012). Equally, there is a significant body of research and practice analysis on international education (Scott 1998; Roberts and Dunworth 2012) and internationalisation of higher education (Knight 2004, 2013; de Wit 2002, 2011; Smith 2010; Tadaki and Tremewan 2013). An important aspect of the studies in this area has been the focus on the need to understand factors influencing international student decision-making process (Mazzarol and Soutar 2002; Maringe and Cater 2007), to 'market' higher education (Shanka, Quintal and 
Taylor 2005; Hemsley-Brown 2012; Ross and Grace 2012) and the implications and pressures that such marketing has placed on the academic communities (Paswan and Ganesh 2009; Woodall, Hiller and Resnick 2014). Previous studies on international recruitment agents have considered the influence of recruitment agents on Thai students' decision making process (Pimpa 2003), Chinese students' rationale for using or not using agents when applying to US universities (Hagedorn and Zhang 2011) and sources of power for UK universities in their relationship with Chinese recruitment agents (Yen, Yang and Cappellini 2012). However, no single academic study has looked at how international recruitment agents are managed.

The major contribution of this study is therefore twofold. Firstly, it enhances understanding of the control mechanisms used by higher education institutions (the principal) in the principal-agent relationship, focusing on how control measures might be mediated by the power dynamics between the two parties. Secondly, it extends the studies of power and agency into the education sector, an area that is underexplored so far. This allows space for theory development through empirical data analysis into higher education, which has been called for by Ashwin (2012).

\section{Agency theory}

An agency relationship exists 'whenever one party (the principal) depends on another party (the agent) to undertake some action on the principal's behalf' (Bergen, Dutta and Walker 1992, 1). Agency theory, developed over the last half-century (Jensen and Meckling 1976), examines how efficiency can be achieved from the principal's perspective. Two underlying assumptions of agency theory are: 1) principals and agents will each be motivated by self-interest, with varying assessments of risk and risk preference; and 2) agents will only selectively disclose information to the principal, making it difficult for the principal, in the pre-contract phase, to select the most suitable 
agent and, post-contract, to monitor the activities of agents (Ennew, Ünüsan and Wright 1993).

Agency problems arise both from partial goal incongruence and from information asymmetry. Goal incongruence refers to divergent views on the goals of the principal/agent relationship or different ideas about how to achieve agreed outcomes (Dou et al. 2010; Jap and Anderson 2003). This is closely linked to the 'moral hazard' of the agent, a term used to refer to the potential of agents to operate in their own selfinterests (Jensen and Meckling 1976; Eisenhardt 1989; Quinn and Doherty 2000). Information asymmetry takes the form of pre-contractual 'hidden information' and postcontractual ‘hidden action’ (Bergen, Dutta and Walker 1992).

To mitigate such risk, Eisenhardt (1989) suggested that the principal faces two choices: a) to invest in information gathering or monitoring system to reduce information asymmetry and b) to incentivise the agents so that the goals of the two parties are more aligned. Sharma (1997) has identified four types of restraints on the potentially opportunistic behaviour of professional agents: self-control (altruism), community control (concerns about reputation), bureaucratic control (structure and systems) and client control (attributes of arrangements between principal and agents such as transaction-specific investments made by the agents).

The focus of the principal's decision lies with determining the most efficient mechanisms to govern a particular relationship. This normally takes the form of formal written contracts and post-contractual monitoring, support and investment. Formal written contracts, 'a key governance role in almost all exchanges' (Burkert, Ivens and Shan 2012), typically record agreements on the rights and obligations of principal and agent as well as processes for dispute resolution (Poppo and Zenger 2002). 
In agency theory, much attention has been paid to different kinds of contracts, with a distinction generally made between outcome-based and behaviour-based approaches (Bergen, Dutta and Walker 1992; Whipple and Roh 2010). The decision to favour one approach over the other has often been seen as based on an assessment of the costs of behaviour monitoring and the costs of shifting the risk to agents. As the cost of monitoring is lower than the cost of shifting the risk to agents, behaviour-based approaches may be more appropriate whilst outcome-based approaches may be more efficient if the cost of monitoring is higher.

Agency theory has been applied in the context of both internal (Kuang and Moser 2009; Mahaney and Lederer 2011; Lo et al. 2011; Hannafey and Vitulano 2013) and external agency relationships (Reuer and Ragozzino 2006; Hodge, Oppewal and Leckie 2013). However, the application of agency theory in the higher education sector barely exists, although practice analysis and observations on the benefits, risks and lessons learned in using international recruitment agents have been reported from both institutional and students' perspectives (Pimpa 2003; Hagedorn and Zhang 2010; Zhang and Hagedorn 2011; Shay, Molony and Mittal 2013; Brabner and Galbraith 2013).

\section{Power and Control}

Power, which is defined as the ability of one individual or group to influence decision variables of another (El-Ansary and Stern 1972; Hunt and Nevin 1974), has often been used interchangeably with the term 'control' in marketing channel literature as noted by Blois and Lacoste (2009). Frazier and Antia (1995), though, argue that the conflation of power with control is a mistake. They suggest that it is erroneous to equate power with the 'authoritative control mechanism, which in turn is equated to unilateral relationships' (324). Power has a wider reference, reflecting 'one firm's potential for influence on another firm's beliefs, attitudes, and behaviour' (324). Control, on the 
other hand, is seen by them as 'the actual impact that a firm has on the decision variables of its channel partner' and as 'a function of power, its communication, and the norms developed during the course of interaction with channel members' (324). Much of the literature on the coercive/non-coercive distinction seems to mix three concepts of power: power, sources of power and use or exercise of power (see Gaski and Nevin 1985; Frazier and Rody 1991; Kumar 2005; Leonidou, Talias and Leonidou 2008; Zhuang and Zhang 2011). This study refers to uses of power.

Coercive use of power normally takes the form of threats or recourse to legal remedies and punishment (Wilkinson 1996), whilst non-coercive use of power may include promises, share of expertise (or information) and consultation (or partnership approach) (Kumar 2005). Non-coercive use of power seems to be closely related to a more recent concept of 'soft power' advocated by Nye (2004) who defined soft power as 'the ability to get what you want through attraction rather than coercion or payments' (34). Studies into the use of power (Frazier and Rody 1991; Quinn and Doherty 2000; Leonidou, Talias and Leonidou 2008) suggest that coercive and non-coercive uses of power have differential impact on the inter-organisational relationship and the effectiveness of use of power depends very much on the power balance of the relationship.

Research shows that non-coercive use of power is generally preferred by the principal to influence the agent's behaviour and enhance control in the contexts of retail franchising (Quinn and Doherty 2000; Doherty and Alexander 2006), manufacturing (Zhuang and Zhang 2011) and education (Yen, Yang and Cappellini 2012). From longitudinal observations of a franchiser-franchisee relationship, Quinn and Doherty (2000) observe that power and control over the agent (franchisee) are closely related to the principal's brand. Branding may be more complex to assess in education than in 
other more commercial and less intangible products. It is clear, however, that the perceived attractiveness of the principal's product to the market allows the principal a more diverse range of options in power and control. Doherty and Alexander (2006) find that the non-coercive approach is employed more by principals even when they possess well-defined brands. They also find that the principal cannot simply alternate between the coercive and non-coercive uses of power because coercive use of power will put the relationship in jeopardy. However, according to Doherty and Alexander (2006), agency theory advocates coercive use of power to maintain control of the agent and avoid the consequence of the potential moral hazard of the agent.

In the higher education sector, Yen, Yang and Cappellini (2012) looked at the power source of universities over agents. Their work was based on interviews with 10 international managers of UK universities with a focus on the Chinese market. They conclude that university ranking is the single most important indicator or source of power for universities but this remains to be tested in other markets. Their study did not look at how the sources of power were related to the actual uses of power by both parties or how power dynamics might have affected the management of agents. It is plausible that what distinguishes powerful and less powerful principals is how they use (or choose not to use) their power. For example, all contracts give universities the legitimate power to terminate relationships with agents. That said, for the same type of breach of contract, different universities may take different approaches to resolve the issue.

Whilst spectrums of views are held by UK universities about agents (Matthew 2012), almost all of them make direct use of recruitment agents, many of them relying heavily on those agents to meet annual targets. In all cases, the agent is expected to possess a skill, knowledge, experience or contacts which it is advantageous to the owner 
or provider of the commodity to utilise. The provider or principal believes it to be in his/her best interest to employ the agent and the agent believes it to be in his/her best interest to work with/for the provider. The interests of each, however, are different.

In spite of the commercial nature of international student recruitment there remains an understanding that a university degree is more than a commodity (McQuillan 2014). It is understood and expected to be a partnership between the institution and the student in which both contribute to the success of the outcome. It is not possible to purchase a degree but only to secure the opportunity to work towards attaining one. This concept of the service rather than the commodity aspect of HE, of its value as well as its price all make the selection and management of education agents a very sensitive and difficult task. Understanding the role of agents, the possible risks of engaging them and the interrelations of power and control in agency management constitutes the aim of this study. Specific questions addressed in this research were:

(1) What are the key issues faced by HEIs when working with international recruitment agents?

(2) What governance and control mechanisms have been adopted by the institutions to minimise agents' opportunistic behaviour?

(3) What part does power play in the control mechanisms afforded to the institutions?

\section{Research design}

Yin (2009) advocates the use of multiple sources of evidence. Accordingly, this research adopted a multiple-case approach, allowing for enhanced depth of exploration and the opportunity to identify multiple aspects of power dynamics and the issues of principal/agent relationship for the whole sector. This study employed semi-structured 
interviews and group discussions involving up to six informants from each case institution.

Data were collected from 20 UK higher education institutions, a representative cross-section of the UK sector based on average Universities and Colleges Admissions Service (UCAS) tariff points for new students admitted in 2011-12 as reported by Higher Education Statistics Agency (HESA, 2013). The reason for using UCAS tariff points as a classification criterion is that this focuses on student recruitment and is a clear indicator of market demand. Whilst the data only relate to the undergraduate intake, and are not differentiated between international and UK/EU fee categories of students, the achieved qualifications of all undergraduate entrants provide a sufficiently good guide to the positioning of UK universities in international markets at both undergraduate and taught postgraduate levels, particularly because the common public position of UK universities is that international students are recruited using the same standards as 'home' students. HESA data shows that the UCAS average tariff points for new undergraduate entrants to 154 UK HEIs in 2011/12 ranged from 213 to 608. The range of tariff points in the 20 responding institutions was 251 to 509 (9 below and 11 above 410, the mid-point). According to Matthews (2012), about 6 percent of UK HEIs do not work with agents. Of the 20 responding institutions, one at the higher end has no contractual relationship with external recruitment agents but was included in the study in order to develop an understanding of the reasons for not using external agents. The sample represents 13 percent of the approximate 144 HEIs using recruitment agents and 11 percent of those not using agents.

All UK universities were invited by email to participate in this research. The email recipients were managers with responsibilities for international recruitment (i.e., either international directors or heads of international recruitment or both). Each 
respondent was asked to nominate appropriate colleagues for either a one-to-one interview or a group discussion. The choice was given to suit the institutions' circumstances in order to maximise the number of participants from each institution. Potential participants' job roles require them to undertake extensive overseas travels and the sizes of international recruitment team may vary from single staff member to a team of over 20 officers. In addition, issues explored with senior managers are more strategic and those with officers are more operational.

Where multiple respondents were involved, the line manager (International Director or Head of International Recruitment) was normally interviewed separately and/or, in a couple of cases, interviewed with his/her deputy or international officers. It was felt that officers were more willing to share their experience without their line managers being present. The sample includes 6 institutions with single respondent interviews, 3 institutions with group interviews, 2 institutions with multiple one-to-one interviews and 9 institutions with a mixture of group and one-to-one interviews. Of the six institutions which only offered single person interviews, two were small new universities where the respondents were the only person involved in international recruitment and the management of agents. Altogether, a total of 57 participants were interviewed involving 24 one-to-one interviews and 12 group discussions. Fourteen participants held a senior managerial role - international director or equivalent. Participants' experience in international recruitment ranged from one year to over 25 years and their position ranged from junior to senior levels. Thirty participants had worked in other HEIs prior to joining their current organisation. The territories managed by the international officers interviewed spread to over 60 countries across Africa, the Americas, Europe, Asia and the Middle East. 
Data collection methods and process were negotiated between one of the researchers and the corresponding respondents. Where there were multiple respondents, discussions with senior managers and heads of international recruitment were focused more on background information, reasons for using agents, the key drivers of international recruitment, the process of appointing agents, key challenges of working with agents and their views about power dynamics between the university and its agents. Discussions with international officers were focused on the characteristics of the agents they worked with, various aspects of information asymmetry, goal incongruence, sources of conflicts, coordination and support from both sides, power dynamics and control mechanisms.

One-to-one interviews and group discussions took place at the respondents' place of work, with one exception when video conferencing was used. For each institution, the length of discussions varied from one to three hours, depending on the number of participants involved. Discussions with senior managers all lasted for more than one hour. The data collection was completed in the summer of 2013.

All interviews and discussions were recorded and transcribed. Where multiple interviews were conducted in one institution, the transcripts were combined as one case transcript to enable this exploratory cross-case analysis. The 20 case transcripts were imported to NVivo 10 for analysis. A three-stage method (Bazeley and Jackson 2013) was used to analyse the data. Stage one involved within-case analysis and stage two cross-case comparisons (Eisenhardt 1989). The coding took different forms: a priori coding (Bazeley and Jackson 2013) guided by previous studies in agency relationship and power dynamics, indigenous coding with codes derived directly from data and concept generating coding (Hutchison, Johnston and Breckon 2010). This was an iterative process when data were coded and uncoded and nodes were categorised and re- 
categorised. In order to check the reliability and consistency of the coding, each case was read and coded a second and a third time. Tables 1, 2 and 3 demonstrate how the coding categories were organised. The categories were initially coded as open nodes and categorised and reviewed or renamed at later stage and organised in a parent-child structure. The key issues of working with agents were then cross-tabulated against agency problems that had been used as prompts in the interviews. Further concept development regarding power and control in agency management was completed in stage three when patterns and connections between themes were explored via framework matrices and visualised model (Figure 1) embedded in NVivo10.

\section{Results}

The first set of analyses looks at issues arising from the agency relationship guided by agency theory. This is followed by agency management approaches adopted by the case institutions and the interrelation between power and control in agency management.

\section{Results 1: key issues of using agents}

Issues of working with agents fall into four categories: communication, effectiveness,

ethical issues and quality issues as shown in Table 1 . The majority of issues identified found some explanations through agency theory.

Agency theory assumes that the goals of the principal and the agent are only partly aligned. This was well recognised by the respondents as agents were seen as naturally more profit driven than universities. 'If they had their way, we'd take all the students they send through. So, in that sense it's not aligned'.

Universities are conscious of the need to make contributions to income rather than profit through international student recruitment and indeed the agents are engaged 
in order to make this successful. Universities are expected to maintain quality while securing numbers.

Agency theory also sees inherent problems of pre-contractual 'hidden information' and post-contractual 'hidden action' to use terms of Bergen, Dutta and Walker (1992). Information is hidden during normal due diligence processes of agent selection because agents 'play the game' when completing pro-forma questionnaires and hosting site visits. There is still a significant reliance on blind trust.

You're kind of taking everything on faith. ...There's no column for proof.

Table 1. Key issues of working with agents

\begin{tabular}{|c|c|c|}
\hline Primary descriptors & $\mathrm{n}^{*}$ & Exemplar quotes \\
\hline $\begin{array}{l}\text { Communication } \\
\text { issues }\end{array}$ & 11 & \\
\hline $\begin{array}{l}\text { - Cultural } \\
\text { differences }\end{array}$ & 5 & $\begin{array}{l}\text { It does vary from one country to another and, unfortunately, } \\
\text { countries have the kind of cultural tendencies that are not to } \\
\text { do much in writing. Everything happens face-to-face, by }\end{array}$ \\
\hline $\begin{array}{l}\text { - Poor } \\
\text { communication }\end{array}$ & 10 & $\begin{array}{l}\text { phone. } \\
\text {.. breakdown in communication. ... There is a lot of shouting } \\
\text { down the phone. That can happen with some agents. }\end{array}$ \\
\hline Effectiveness Issues & 16 & \\
\hline $\begin{array}{l}\text { - Contracts not } \\
\text { read or } \\
\text { understood }\end{array}$ & 11 & $\begin{array}{l}\text { It just makes you think, "do they really know what they're } \\
\text { doing," because we've given them this information. It's in the } \\
\text { contract but they obviously haven't read it. }\end{array}$ \\
\hline & 8 & $\begin{array}{l}\text { You build a good relationship with one person and then they left. } \\
\text { Start again from scratch. }\end{array}$ \\
\hline turnover in agents & 7 & [Due diligence] it's probably just scratching the surface. \\
\hline $\begin{array}{l}\text { - Ineffective due } \\
\text { diligence }\end{array}$ & 8 & $\begin{array}{l}\text { Nowhere is more true than China where the approved list is } \\
\text { grey. }\end{array}$ \\
\hline $\begin{array}{l}\text { - Not performing } \\
\text { agents }\end{array}$ & & $\begin{array}{l}\text { We had an agent that in one year sent } 280 \text { complete applications } \\
\text { and we made } 140 \text { offers. No students actually arrived. }\end{array}$ \\
\hline Ethical issues & 16 & \\
\hline - Dishonesty & 2 & $\begin{array}{l}\text { The forgery is the problem in certain countries. ... [one of the } \\
\text { agents] is not honest. He sent commission claims for students } \\
\text { that he's not recruited. He has done all sorts of dodgy things. }\end{array}$ \\
\hline - Misrepresentation & 5 & $\begin{array}{l}\text { Some agents like to present themselves as the representatives of } \\
\text { the university rather than agents. }\end{array}$ \\
\hline - Misselling & 8 & $\begin{array}{l}\text { They promote universities or courses without full understanding } \\
\text { of the nature of the courses and what the students will gain } \\
\text { from it. They might make false promises. }\end{array}$ \\
\hline & 5 & There are disputes between agents about students and their \\
\hline
\end{tabular}


- Poaching students from other agents

- Profit driven agents commission and who got there first.

8 They just want to make the university pay.... get the university they want to work with, get the numbers [students], get higher commission, keep asking for as much as they can, probably get you to give them more marketing budget, if you are giving them already - I think their goals are pretty much decided. It's going to be very much economic financial type.

5 They've got their subagents and the subagents have subagents.

- Subcontracting

Quality Issues

- Lack of diversity

- Low quality control

- Low standards

- Poor service
9

4 And you just end up with applications from that agent for one or two particular courses, without them representing the whole of the offering of the university.

4 ... sending us poorly qualified candidates which we don't want to see in the first place. ...badly completed application forms.

6 If you get 100 applications maybe 50-70 are students who don't quite make the standard and they expect some sort of negotiation.

2 I'm not convinced that they were providing good service to the student.

$* \mathrm{n}=$ number of case institutions coded at each descriptor

The fundamental problem is you don't actually know who the company is ...

you don't have a real idea of who's doing what ... whose role is this and who

the staff are ... There are many things that universities don't know about

them before entering an agreement.

'Hidden action' involves activity (or inactivity) that would be regarded by the university as misbehaviour or misdemeanour. The term 'misbehaviour' is used here to cover a large range that runs from casual mistakes, or inadvertent misselling to potential students, to illegal activity. 'They may promise things that they probably shouldn't have promised'. Possibly some agents are 'falling foul of the bribery legislation'. 'Sometimes there are corrupt agents.'

Another problem of 'hidden action' arises when agency staff do not know enough about the universities they represent, a situation aggravated by high staff turnover in agents as observed by most respondents. The most serious lapses in trust by 
agents concern non-compliance with current UK Visas and Immigration regulations and transgressions under the Bribery Act. 'Considerable concerns' were expressed by respondents about the visa refusal rate for some agents' applicants.

Agency theory suggests that contracts and relational norms are two common mechanisms employed by universities to overcome the problems caused by 'hidden action'. Relational norms such as the British Council's Guide to Good Practice for Education Agents (2002), endorsed by QAA (2012), include honesty, acting fairly and in the best interest of students, and compliance with all local laws, regulations and official policies. Universities may highlight relational norms in a handbook and check on performance through the training and mentoring of agents.

Agency theory suggests that universities may choose between a behaviour-based contract and an outcome-based contract. However, the data showed that the contracts UK universities enter into with agents are, typically, commission-based (realised outcome) with roles, responsibilities and codes of conduct included as conditions. It might be believed that performance measurement would be simplified with this type of contract.

There was a striking lack of confidence among respondents that agents actually read and understand provisions about conduct. 'Because somebody signed a contract, doesn't necessarily mean that they've read it'. With larger agencies there is no indication that behavioural restraints were actually cascaded down to the operational staff. Apart from agreements on commission and support, a contract with careful terms and conditions may only be a 'just in case' document to satisfy universities' own internal audit requirements.

It was also clear that the contract was not always enforced. Many respondents preferred to let the contract run its course if they were not happy with a particular agent. 
Therefore, this study concurs, in HE settings, with Quinn and Doherty's (2000) finding that "the contract itself was virtually useless in terms of maintaining control over the agent's behaviour'(367).

\section{Results 2: power and control in governing the agency relationship}

If the contract itself does not provide a reliable safeguard for universities, questions need to be asked with regards to what measures universities take to control agents' behaviour and to motivate the agents to achieve outcomes desired by the universities. There were noticeable differences in the approaches taken in terms of control mechanisms and use of power.

Agency theory suggests that in order to avoid the problems of 'hidden action', and to motivate agents to produce results in line with the universities' goals, universities need to decide how they incentivise agents, how they monitor their operations, and how they enforce relational norms or codes of conduct. Data suggested a broad distinction between income-driven and performance-driven approaches (see Table 2). The performance-driven approach is concerned with how the agency achieves its results as well as the realised outcome whilst the income-driven approach is mainly concerned with results.

Table 2: Control mechanisms used by UK universities in agency management

\begin{tabular}{|c|c|c|}
\hline Primary descriptors & $\mathrm{n}^{*}$ & Exemplar quotes \\
\hline Performance driven & 10 & \\
\hline - Annual review & 7 & $\begin{array}{l}\text { We have KPIs based on each slice of the process. We audit them all the } \\
\text { same. We look at the types of applications they're sending in, look at the } \\
\text { way they work, whether they abide by the things we ask them to do. } \\
\text { Then the international officer will recommend either to terminate the } \\
\text { contract or to continue. }\end{array}$ \\
\hline $\begin{array}{l}\text { - Tiered agents } \\
\text { management }\end{array}$ & 5 & $\begin{array}{l}\text { They have to start off as silver and it acts as a probationary period. There } \\
\text { has been progression from silver to gold and also demotion from gold to } \\
\text { silver. }\end{array}$ \\
\hline
\end{tabular}




\begin{tabular}{|c|c|c|}
\hline $\begin{array}{l}\text { - Trial period } \\
\text { - Very selective }\end{array}$ & $\begin{array}{l}2 \\
6\end{array}$ & $\begin{array}{l}\text { We will have them without commission fee for a year. } \\
\text { Generally we try to work with just a couple of agents in each market. }\end{array}$ \\
\hline Income driven & 17 & \\
\hline $\begin{array}{l}\text { - Audits based on } \\
\text { numbers only }\end{array}$ & 7 & $\begin{array}{l}\text { We audit their performance number wise at the end of the year. ... numbers } \\
\text { against expectation of numbers ... conversions, number of applications. }\end{array}$ \\
\hline $\begin{array}{l}\text { - No behavioural } \\
\text { issues identified }\end{array}$ & 4 & $\begin{array}{l}\text { It's pretty surprising to us if they do behave in an inappropriate way.... If } \\
\text { we had to replace them, that would probably mean that they've gone } \\
\text { bust. }\end{array}$ \\
\hline $\begin{array}{l}\text { - No formal } \\
\text { procedure }\end{array}$ & 4 & $\begin{array}{l}\text { I don't have any formal procedure. ... I will sit down and have that } \\
\text { discussion especially where an agent is under performing. And it will } \\
\text { usually be along the lines of, "Well we've invested this and this and this } \\
\text { with you last year and we haven't seen that return. Is there anything else } \\
\text { that we can do to improve this?" }\end{array}$ \\
\hline - Targets & 4 & $\begin{array}{l}\text { We normally set a target -- a realistic target with something for them to } \\
\text { work to. }\end{array}$ \\
\hline $\begin{array}{l}\text { - Variations based } \\
\text { on numbers }\end{array}$ & 10 & $\begin{array}{l}\text { So we just have a standard rate for signing with new agencies. ...to a } \\
\text { certain time, this could be raised. So we don't have only one sort of rate. } \\
\text { It's totally tied to recruitment levels. }\end{array}$ \\
\hline
\end{tabular}

$* \mathrm{n}=$ number of case institutions coded at each descriptor

Another dimension of governance is the use of power by the principal. On the basis of qualitative data collected it is possible to see some common patterns of behaviour, as described by respondents. Some institutions show an obvious reluctance to operate coercively, whatever the contract may permit, whereas others will not tolerate agents

Table 3. Use of power by UK universities in agency management

\begin{tabular}{|c|c|c|}
\hline Primary descriptors & $\mathrm{n}^{*}$ & Exemplar quotes \\
\hline Coercive use of power & 11 & \\
\hline - Dismissal & 6 & $\begin{array}{l}\text { We can terminate if they fail in any of those four areas I referred to } \\
\text { within the student application process. }\end{array}$ \\
\hline - Legal action & 1 & We have taken legal action against a ... company. \\
\hline - Threat & 1 & $\begin{array}{l}\text { There are a couple of agents have said it's not worth doing it. "Fine } \\
\text { then. When it comes to renewing your contract, that will be taken } \\
\text { into account." }\end{array}$ \\
\hline - Tough in negotiation & 10 & $\begin{array}{l}\text { This is the agreement, this is the terms, it's non-negotiable.... [For } \\
\text { a popular programme] the process was to cut the commission by } \\
5 \% \text { from } 10 \% . . . \text { that's it, we're not paying any more. }\end{array}$ \\
\hline Non-coercive use of power & 17 & \\
\hline - Compromise & 4 & $\begin{array}{l}\text { There is a bit of give and take I think. ... additional commission } \\
\text { possibly. }\end{array}$ \\
\hline - Extra financial support & 12 & [for agents visiting the UK campus] we pay for their flight and \\
\hline
\end{tabular}




\begin{tabular}{|c|c|c|}
\hline & & $\begin{array}{l}\text { cover their hotel. ... extra payment in terms of commissions, } \\
\text { guarantees that you would do a certain number of events with } \\
\text { them which tend to be quite expensive, pay for additional things } \\
\text { such as advertising. }\end{array}$ \\
\hline - Flexible & 10 & $\begin{array}{l}\text {... varying ones (agreements), different ones for India, different } \\
\text { ones for China. ... the targets that the university has is obviously } \\
\text { quite flexible. }\end{array}$ \\
\hline - Implicit discontinuation & 9 & $\begin{array}{l}\text { We just let it run its course. Sometimes they're just oblivious to the } \\
\text { fact they have an out-of-date contract. }\end{array}$ \\
\hline - Partnership approach & 7 & $\begin{array}{l}\text { I view it as a partnership. I think I'm probably more unique in that } \\
\text { sense, I think a lot of institutions see the agent relationship as } \\
\text { being master servant. }\end{array}$ \\
\hline - Personal relationship & 6 & $\begin{array}{l}\text { Obviously if there is a better personal relationship then it is likely } \\
\text { that more business will flow. But it's also a case that developing } \\
\text { a personal relationship actually means there is greater trust } \\
\text { between the parties.... I have good personal relationships with } \\
\text { the agents I work with. }\end{array}$ \\
\hline - Responsive & 6 & $\begin{array}{l}\text {.. rapid responses to agent inquiries. ... we'd probably turn around } \\
\text { an offer within a couple of days. }\end{array}$ \\
\hline - Reward & 8 & $\begin{array}{l}\text { We have incentivizing schemes. ... we will be there [education } \\
\text { exhibitions] as a reward for good performance. }\end{array}$ \\
\hline
\end{tabular}

$* \mathrm{n}=$ number of case institutions coded at each descriptor

who misbehave and present a firmer position than others. Coercive use of power

involves dismissal, legal actions, threats and not giving in in negotiations whilst non-

coercive use of power takes the forms of compromise, being responsive and flexible,

giving rewards, developing personal relationship, adopting a partnership approach and

unwillingness to explicitly terminate contracts. Table 3 provides some exemplar quotes

of those categories.

Based on the categorisation of the approaches of control and the use of power, a

conceptual model of agency management has emerged from the data through the

visualised modelling technique embedded in the NVivo (Figure 1). Case A was not

included in this figure as this is the institution not having contractual relationship with agents. 

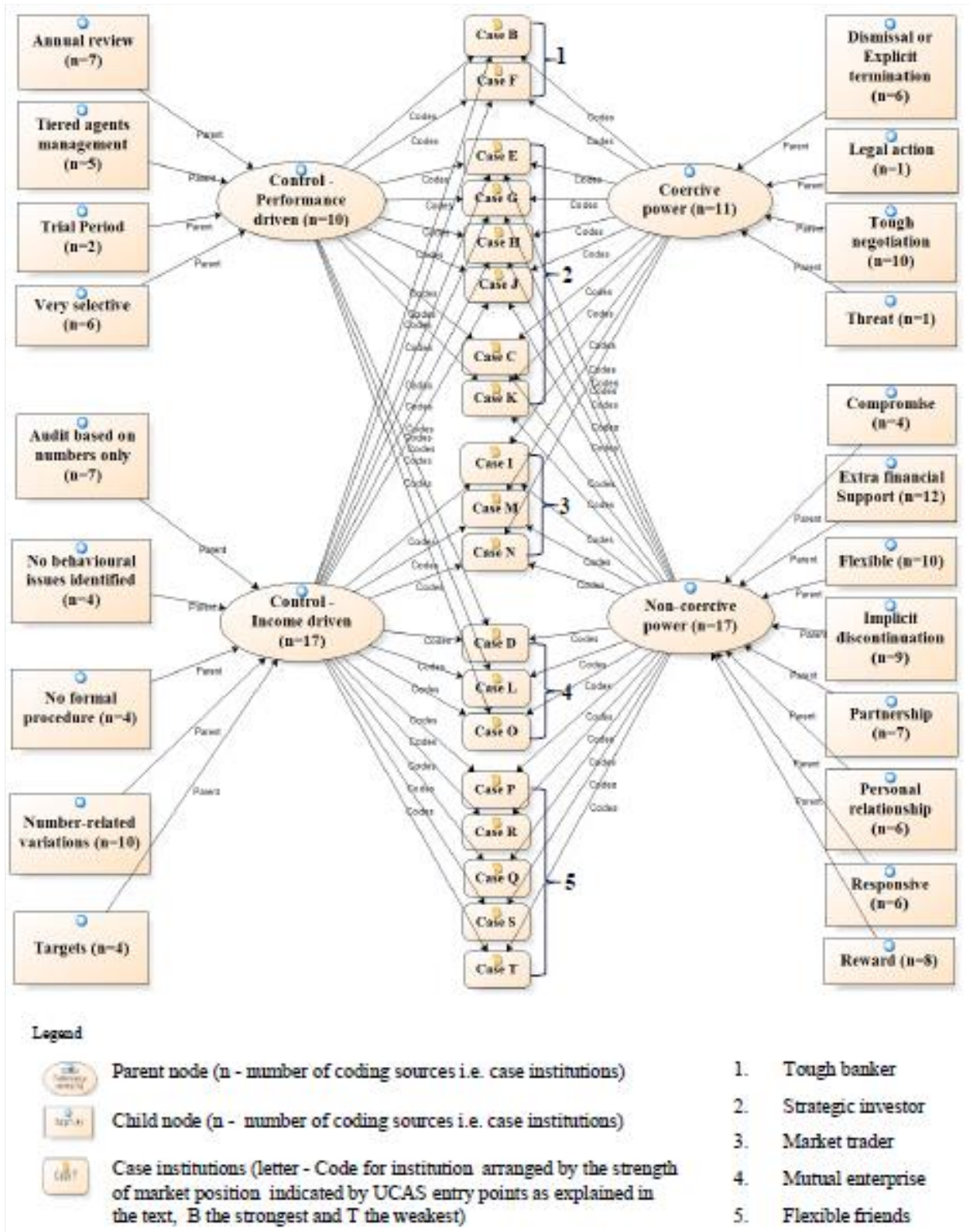

Figure 1. Power and control in managing agency relationship

As shown in Figure 1, the 19 case institutions using recruitment agents can be grouped into 5 categories as explained below. Inevitably, there is a high degree of generalisation and summary, particularly when universities have very many agency relationships. In addition, some universities may have 'high demand' programmes which adopt, or urge the university to adopt, different approaches. Furthermore, some universities may have a general approach but international officers are allowed to manage 'their' agents differently. Some universities could be fitted neatly into categories but others (the 6 case institutions in the Strategic Investor group) were more difficult to place. 
Whilst accepting that the way in which relationships are actually managed is critical, and may vary in a single institution, the development of five descriptive categories was found to be informative. As summarised in Table 4, the five categories are: Strategic investor, Market trader, Mutual enterprise, Flexible friends and Tough banker.

The Strategic Investor group includes institutions that have a strong market position and are very concerned with both protecting their brand and achieving efficiency.

If we think that an agent is dangerous to our reputation, they go. We had a case with an Indian agent that sent us about 20 students in one year. And then we discovered through careful spotting that there was a forged signature ... we terminated the contract immediately.

Strategic investor institutions have developed a very proactive management system to incentivise good behaviour and performance improvement. This includes a tiered system of agents, formal annual review and target setting.

We have 'Silver' and 'Gold' agents, depending on the quality of their work, and I stress quality not quantity of referrals or recruitment. Agents will be provided with either a Gold or Silver level of support. There is also a slightly different rate of commission.

Table 4. Power and control in governing outcome-based agency relationship

Control measures 
Hybrid

(coercive and noncoercive power)

Non-coercive

power

Coercive power
Strategic Investor

- Selective and reactive

- Work with medium high number of agents

- Standard commission based starting point but willing to be flexible and invest in supporting joint marketing activities

- Proactive management and prevention of misbehaviour

- Realistic targets

\section{Mutual Enterprise}

- Work with medium number of agents

- Enhanced levels of commission, bonus and other incentives

- Prepared to invest in joint marketing activities

- Strong relationship with agents and support

- Agents seen as key to achieving volume targets

\section{Market Trader}

- Work with high number of agents

- Standard rate but prepared to make exceptions

- Minimum investment in support and enforcement

- Set targets

- Tough in negotiation

\section{Flexible Friends}

- Not many agents (due to difficulty of getting agents interested)

- Friendly and flexible

- May pay high commission

- Happy for one or two students sent by each agent every year as long as they are getting something from the agents

\section{Tough Banker}

- Very selective with small number of agents

- Trial periods

- High level of support for agents

- Standard or below standard commission rate

- Targets

- Tight watch of agents' behaviour and enforcement of codes of conduct

- Zero tolerance of misbehaviour

It's important to understand of course that we axe agents as well as take them on. ... Once an agent signs it's an absolutely fundamental process that the annex of the contract contains a three year business plan with target numbers.

They can be 'hard ball' in negotiation: 
And I think if we ever got to a position where somebody was trying to extract power and influence, I think we will just terminate the contract actually. ... They wanted to be able to change the rates, but I said: 'No, go away. I'm not interested. I set the rates, you don't.'

However, these institutions will also support agents and work in partnership with them, and they do not work with too many agents because of the cost of such support.

Ever since appointment I have been very sure that agents are definitely a vital tool in terms of recruitment. We are not afraid to take action. ... We do sponsor familiarization trips, where we will pay for agents to come over and visit and put them up at the university to look around us..... We would prefer to work with as few agents as possible but we will never grant exclusivity or a monopoly.

The Market Trader group tends to work with more agents than any other group (in one case, more than 200 agents; in another university one International Officer manages 38 agents which compares to 1.5 to 2 agents to one international officer in 'top end' universities).

Market trader institutions are likely to use sliding commission to incentivise agents and they believe they have got fairly high power in the agency relationship:

So essentially we are the power holders. We have the power to select. We have the power to terminate. We have the power to change the terms or conditions of our agreement. So I would say we are generally largely the power holders. And that is the position we have to be in.

These institutions do not shy away from using coercive threats, such as termination or variation in terms and conditions. Reasons for termination tend to be income-driven. They are not too concerned with the potential retaliation. 
And if they haven't been able to meet the level of recruitment, why have them on our books and risk our reputation.

Their support to agents and performance monitoring tend to be a little more ad hoc.

We haven't got it formally in place but we know which ones are the good ones, which ones we support the most, which ones we don't support as much because they don't send as many students.

The Mutual Enterprise group includes institutions which self-define as entrepreneurial with ambitious aspirations. They tend to avoid the use of coercion because they wish to minimise the 'likelihood of retaliation' and to 'develop a strong relationship' (Frazier and Rody 1991). Some institutions would see themselves as part of the 'squeezed middle'.

Institutions in this group are more likely than many to have long-lasting agency relationships. Developing strong relationships with agents is a key characteristic. Institutions in this category receive a very high percentage of their student intake via agents (with the highest percentage being 55\%).

Institutions in this group do not work with too many agents and they will often provide strong support to agents to help them achieve results.

We don't work with a huge number of agents in any of our markets. Ideally we want ... loyalty. Obviously it works both ways, so I think we get more out of agents. We don't want to spread ourselves too thin.

We treat agents as our customers even though we're their customers. We've taken a decision to treat them as a customer and to build a good rapport with them.

Given the effort devoted to developing close working relations, relationships endure. 'We don't have many problems with agents. We have some that are underperforming 
but we keep giving another year or two'.Contracts may, however, have been terminated if there is no business.

Another respondent from a university in this group took a similar view about discontinuation of agency relationships:

We haven't had to terminate a contract but we have one that has expired and we just haven't renewed it.

The Flexible Friends group also tends to avoid using coercion. This set does not have a strong market position, as indicated by the UCAS points score of undergraduate entrants. Their weak position or lack of power is well reflected in the difficulty they found in signing up agents:

I found it more difficult than I thought ... to attract appropriate agents. I have had refusals ... people saying 'we don't want to represent you' ... hit rate may be one in three.

They were saying: 'we don't want to work with you.' ... It was this idea of us seeking agents, which is quite different.

The difficulty of finding agents can lead some universities signing up agents who 'don't have an office and don't have a business account to pay into'.

This group of universities tends to rely on being flexible and supportive in working with agents. They tended to pay higher commission for realised outcome and very often felt more obliged to share or cover the costs of marketing activities undertaken by the agents.

I think we're just grateful for applications... we need to be kind of more flexible with some agents to try and nurture that relationship in the first place. 
...you've got to give the $£ 4,000$ or $£ 5,000$ or $£ 6,000$ or $£ 8,000$ or $£ 10,000$

whatever it is upfront and then support that agent because it's a two-way street.

This group is outcome-focused and more tolerant of misbehaviours than any other group, as indicated by these two respondents:

Performance monitoring? It's based on the number of students.

We don't sever any contracts mid-term. The worst we can do is not to renew the contract.

Finally, the Tough Banker group of universities have high status and enjoy a strong market position. In the sample, this group was small and, consequently, it was not found realistic to distinguish between 'performance-driven' and 'income-driven'. However, in practice, the stress on branding by institutions in this group means that any damage to the brand by unapproved performance would normally result in retributive action. Respondents from this group declared a readiness to use power coercively.

We can always drop agents; we found they were using a subagent. ... So we found out today, and we terminated the next day and we haven't worked with them.

Coercive use of power is also manifested in the way this group appoints agents and manages their performance. In markets with high demand, they may not make any contractual relationship with agents at all.

In markets where agents are used, the number of agents is closely restricted. The preference is to work with a very small number of agents on exclusive or semiexclusive terms: 'we want to be represented by somebody whom we have real confidence in and we know very well, we can trust to represent the university in a way 
that we wanted to be represented.' Sometimes this results in an agency relationship with alumni.

Working closely with a small number of agents is linked to close monitoring of the agents' performance and with effective support for agents.

So in each country, the average is anything between one and two.... We try and make sure that whenever we go to a country we see all our agents. ... So we can keep quite a tight watch.

In this institution I only work with one agent. But when I was working with large numbers of agents (in a previous institution) and we're talking 50 - 100 agents, the level of support that I could provide wasn't equal.

For institutions in this group, their approach is based on a strong view about the value of the brand. They are very concerned to protect their brand from opportunism and are consequently more prepared to use or threaten to use, power coercively.

I guess it's the alumni, the kind of the quality of the degrees and their performance ... how well they do in their careers. ... We've got schools and families that kind of keep sending students, you know, like the first kid, second sibling and the third, all just keep coming. So it's largely the brand and the quality of our research and our degrees.

Another practice no other group would have considered is to insist on a trial period, without a commission fee, for a year for new agents. During this period they need to show that 'they understand us, they understand the policy, they understand our programs and the type of students we're looking for'.

The performance review is 'done in such a way that it does kind of all lead to the renegotiation of contract'. 
if they don't perform well that year, they need to explain why not, after a year if that's okay we can let them limp along, see if they might improve. And if they don't, then we just terminate that one.

These institutions are also target driven. The agent's motivation to perform well comes from the advantages of contract renewal rather than any direct financial incentive.

\section{Discussion and conclusions}

This study aimed to analyse the practices of agent management and to explore the ways in which power and control decisions interrelate in agency management. The analysis of responses from 20 institutions reconfirmed, in the higher education setting, the results of previous studies in agency theory that with the use of agents come inherent problems of partial goal incongruence and information asymmetry in the forms of 'hidden information' and 'hidden action'. This concurs with Inderst and Ottaviani’s (2009) proposition in relation to general selling firms that a lack of transparency in commission structure and other incentive mechanisms would weaken the principal's own power position and encourage misselling by agents. Agency theory would posit that contracts and relational norms are two common mechanisms to overcome those problems. However, the data in this study suggest that contracts and relational norms on their own are not effective measures because the respondents have expressed little confidence in agents even reading the contracts and codes of conduct sent by the universities.

The distinction between behaviour-based and outcome-based contracts as control mechanisms suggested in the agency theory was not helpful when applied to external agency relationships in HEIs which are normally commission-based by nature. Therefore, there was a need to develop further the decision criteria for outcome-based contractual relationships. Within outcome-based contractual relationships it is possible to see a distinction between the performance-driven approach (how the outcomes are 
achieved) and the income-driven approach (whether the outcomes are achieved). The joint consideration of power and control provided a very useful framework for analysing the management of the external agency relationship for HEIs, providing a clear five-category typology. The five distinct styles of agent management identified in this study represent a valuable start to developing a deeper and more nuanced understanding of how agent management practices can vary in the international student recruitment sector.

The findings from this study contribute to the current literature in both agency theory and power studies by the inclusion of UK HEIs for the first time. Firstly, they confirm previous findings by Quinn and Doherty (2000) that coercive and non-coercive uses of power and control are interrelated dimensions of agent management and that the locus of power does not always lie with the principal. The matrix of power and control, which was seen in Table 4, highlights how this interrelationship can be manifested in management operations. Secondly, they show that non-coercive use of power by HEIs can be effective if backed up by either the willingness to use coercive power (Strategic investors and Market traders) or by the high dependence of agents on the principal (Mutual Enterprise). Evidence from this study also demonstrates that agency theory, originated from studies into internal agencies (Eisenhadt 1989), needs to be treated with caution when applied to external agency relationships, particularly when cultural, legal and economic differences make monitoring and enforcement extremely difficult. It illustrates too the differences of practice that occur in a single sector viz HE, when the branding of the institutions in that sector is so varied. The significance of HE and its academic, cultural, diplomatic and financial contribution to the wider society has increased awareness of the need for its systems and codes to be regularly evaluated and 
improved. It is likely, therefore, that once understood, best practice will increasingly be adopted in agency management, as in other developing aspects of marketisation.

\section{Managerial implications and future research}

It is clear that for most universities, agents play a very important role in helping them achieve student recruitment targets. Universities spend considerable time, effort and financial resources (e.g. commission, incentive payments, and marketing budgets) on agents and so it is vital that they have robust processes in place for sourcing, appointing, monitoring, and, if necessary, terminating agent relationships. Evidence from this study suggests there are varying practices across the sector. Those seen to be in a strong position of power position are more likely to use their power coercively, while those that seem to be in a weaker position use whatever power they may have in a noncoercive way. In most cases more could be done to ensure more beneficial returns on investment in agent relationships and with greater protection for universities which work with them. Of course, much will depend on an individual institution's risk appetite: how much they are willing to invest (time and money), what sorts of agencies they are happy to contract with, and what type of contractual relationships they will accept. But there is a bottom line of legal and regulatory frameworks which all universities must adhere to. Pressure to achieve targets may be high but compromising on the basic requirements is a high risk approach.

The findings of this study provide a better understanding of the key issues of working with agents and the variations of agency management through the UK HE sector. The five styles of control decision-making can serve as a template for practitioners in assessing and planning their efforts and resources for international student recruitment activities. It is argued that greater attention needs to be paid by 
university managers to understanding their sources of power and how to use power effectively and efficiently in incentivising agents and enforcing compliance.

Taking into account the findings of this research, some recommendations to the UK Higher education sector may be made.

- Develop clear agency strategies and understand why they are working with agents.

- Look at the appointment of agents as a tendering process as would normally be the case in the UK for contracts of a certain value.

- Develop clear and robust due diligence processes for the appointment of agents and ensure a continuous process of due diligence through training, information exchange, support, performance review and performance improvement.

- Ensure that contracts contain sufficient specification of behaviour norms, thus making it possible to assess performance qualitatively as well as quantitatively.

- Do not make assumptions about the relative power dynamics between one's own university and current or future agents. University status or ranking is not the only determinant of power.

Finally, while agents are, and it is believed will continue to be important components of successful international student recruitment campaigns, the current lack of transparency about their use by universities could cause significant harm to the sector. Universities should ensure that future students are given transparent advice about university options and understand clearly the basis on which that advice is given. The authors believe that greater transparency about agent use and the basis of the relationships between them and universities, including commission payments and other incentives, is vital to the sector's health. 
The findings of this study were based on data collected from UK-based higher education institutions and represented perspectives from the university side of the agency relationship. If the debate on the use of agents is to be moved forward, further research is needed on agents' perspectives. It would also be helpful to undertake a similar data collection exercise in the HE sector of other countries where the use of agents is more regulated than in the UK.

\section{Acknowledgements}

The authors would like to thank colleagues in the participating institutions for the generous contribution of their time and the sharing of information and opinions. The authors also gratefully acknowledge the financial support provided by the British Council for this project.

References:

Ashwin, p. 2012. How often are theories developed through empirical research into higher education? Studies in Higher Education 37 (8): 941-955.

Bazeley, P., and K. Jackson. 2013. Qualitative data analysis with NVivo. London: Sage Publications Limited.

Bergen, M., S. Dutta, and O.C. Walker. 1992. Agency relationships in marketing: A review of the implications and applications of agency and related theories. Journal of Marketing 56 (3): 1-24.

BIS (Department for Business, Innovation and Skills). 2013. International education: Global growth and prosperity. From https://www.gov.uk/government/publications/international-education-strategyglobal-growth-and-prosperity (accessed December 1, 2013).

Blois, K., and S. Lacoste. 2009. Power in business -to-business relationships - some problems of interpretation. 25th IMP-conference in Marseille, France.http://www.impgroup.org/uploads/papers/7332.pdf (accessed November 20, 2013). 
Brabner, R. and G. Galbraith. 2013. Using international recruitment agents: risks and regulations? Leadership Foundation for Higher

Education.http://www.lfhe.ac.uk/en/research-resources/publishedresearch/research-by-theme/internationalisation/using-international-recruitmentagents.cfm (accessed December 15, 2013)

British Council. 2002. Guide to good practice for education agents. http://www.britishcouncil.org/guide_to_good_practice_for_education_agents3.pdf (accessed December 1, 2013).

Burkert, M., B.S. Ivens, and J. Shan. 2012. Governance mechanisms in domestic and international buyer-supplier relationships: An empirical study. Industrial Marketing Management 41 (3): 544-556.

Doherty, A.M., and N. Alexander. 2006. Power and control in international retail franchising. European Journal of Marketing 40(11/12): 1292-1316.

Dou, W., H. Li, N. Zhou, and C. Su. 2010. Exploring relationship satisfaction between global professional service firms and local clients in emerging markets. Journal of International Business Studies 41 (7): 1198-1217.

Eisenhardt, K.M. 1989. Agency theory: An assessment and review. Academy of Management Review 14 (1): 57-74.

Ek, A., M. Ideland, S. Jönsson, and C. Malmberg. 2013. The tension between marketisation and academisation in higher education, Studies in Higher Education 38 (9): 305-1318.

El-Ansary, A.I., and L.W. Stern. 1972. Power measurement in the distribution channel. Journal of Marketing Research (JMR) 9 (1): 47-52.

Emerson, R.M. 1962. Power-dependence relations. American Sociological Review 27 (1): 31-41.

Ennew, C., Ç. Ünüsan and M. Wright. 1993. Power and control in distribution channels: The case of automobile distribution in turkey. Journal of Marketing Management 9 (4): 393-403.

Frazier, G.L., and K.D. Antia. 1995. Exchange relationships and interfirm power in channels of distribution. Journal of the Academy of Marketing Science 23 (4): 321-326.

Frazier, G.L., and R.C. Rody. 1991. The use of influence strategies in interfirm relationships in industrial product channels. Journal of Marketing 55 (1): 52-69. 
Frazier, G.L., and J.O. Summers. 1984. Interfirm influence strategies and their applications within distribution channels. Journal of Marketing 48 (3): 43-55.

Gaski, J.F. 1986. Interrelations among a channel entity's power sources: Impact of the exercise of reward and coercion on expert, referent, and legitimate power sources. Journal of Marketing Research (JMR) 23 (1): 62-77.

Gaski, J.F., and J.R. Nevin. 1985. The differential effects of exercised and unexercised power sources in a marketing channel. Journal of Marketing Research (JMR) 22 (2): $130-142$.

Hagedorn, L. S., and L.Y. Zhang. 2011. The use of agents in recruiting chinese undergraduates. Journal of Studies in International Education 15 (2): 186-202.

Hannafey, F.T., and L.A. Vitulano. 2013. Ethics and executive coaching: An agency theory approach. Journal of Business Ethics 115 (3):599-603.

Hemsley-Brown, J. 2012. The best education in the world: reality, repetition or cliché? International students' reasons for choosing an English university, Studies in Higher Education 37 (8): 1005-1022.

HESA (Higher Education Statistics Agency). 2013. Average tariff of entrants to FT UG courses by institions 2011/12. https://heidi.hesa.ac.uk/default.aspx (accessed March 6, 2014).

HESA (Higher Education Statistics Agency). 2014. Income and expenditure of HE institutions. http://www.hesa.ac.uk/index.php?option=com_content\& task=view\&id=3140\&Itemid=161 (accessed March 6, 2014).

Hodge, C., H., Oppewal and C. Terawatanavong. 2013. Determinants of franchise conversion: A franchisee perspective. European Journal of Marketing 47 (10): 1554-1575.

Hunt, S. D. and J. R. Nevin. 1974. Power in a channel of distribution: Sources and Consequences. Journal of Marketing Research XI(2):186-193.

Hutchison, A.J., L. H. Johnston, and J. D. Breckon. 2010. Using QSR-NVivo to facilitate the development of a grounded theory project: an account of a worked example. International Journal of Social Research Methodology 13 (4): 283302.

Inderst, R. and M. Ottaviani. 2009. Misselling through agents. American Economic Review 99 (3): 883-908.

Jap, S.D., and E. Anderson. 2003. Safeguarding interorganizational performance and continuity under ex post opportunism. Management Science 49 (12): 1684-1701. 
Jensen, M., and W. Meckling. 1976. Theory of the firm: managerial behavior, agency costs, and ownership structure. Journal of Financial Economics 3 (4): 305-60.

Knight, J. 2004. Internationalization remodeled: Definition, approaches, and rationales. Journal of Studies in International Education 8 (1): 5-31.

Knight, J. 2013. The changing landscape of higher education internationalisation - for better or worse? Perspectives: Policy and Practice in Higher Education 17 (3): 84-90.

Kuang, X., and D.V. Moser. 2009. Reciprocity and the effectiveness of optimal agency contracts. The Accounting Review 84 (5): 1671-1694.

Kumar, N. 2005. The power of power in supplier-retailer relationships. Industrial Marketing Management 34 (8): 863-866.

Leonidou, L.C., M.A. Talias, and C.N. Leonidou. 2008. Exercised power as a driver of trust and commitment in cross-border industrial buyer-seller relationships. Industrial Marketing Management 37 (1): 92-103.

Lo, D., M. Ghosh, and F. Lafontaine. 2011. The incentive and selection roles of sales force compensation contracts. Journal of Marketing Research 48 (4): 781-798.

Mahaney, R.C., and A.L. Lederer. 2011. An agency theory explanation of project success. Journal of Computer Information Systems 51 (4): 102-113.

Maringe, F., and S. Carter. 2007. International students' motivations for studying in UK HE: Insights into the choice and decision making of African students. International Journal of Educational Management 21 (6): 459-75.

Matthews, D. 2012. Grand fee paid for each foreign student, Times Higher Education July 2. http://www.timeshighereducation.co.uk/news/grand-fee-paid-for-eachforeign-student/420468. article (accessed 18 March 2014).

Meehan, J., and Wright, G.H. 2012. The origins of power in buyer-seller relationships. Industrial Marketing Management 41 (4): 669-679.

Merritt, N.J., and S.J. Newell. 2001. The extent and formality of sales agency evaluations of principals. Industrial Marketing Management 30 (1): 37-49.

Mazzarol, T. and N. Soutar. 2002. Push-pull factors influencing international student destinationl choice. International Journal of Education Management 16 (2): 8290.

McQuillan, M. 2014. Cool it, Which? A degree is not a fridge. Times Higher Education, February 13, 2014, http://www.timeshighereducation.co.uk/comment/opinion/ 
cool-it-which-a-degree-is-not-a-fridge/2011229.article (accessed 18 March, 2014).

Nye, J. 2004. Soft power and higher education. The Internet and the University. http://net.educause.edu/ir/library/pdf/ffpiu043.pdf (accessed November 20, 2013).

Paswan, A., and G. Ganesh. 2009. Higher education institutions: Satisfaction and loyalty among international students. Journal of Marketing for Higher Education 19 (1): 65-84.

Pimpa, N. 2003. The influence of peers and student recruitment agencies on Thai students' choices of international education. Journal of Studies in International Education 7 (2): 178-192.

Poppo, L., and T. Zenger. 2002. Do formal contracts and relational governance function as substitutes or complements? Strategic Management Journal 23 (8): 707-725.

QAA (The Quality Assurance Agency for Higher Education). 2012. International students studying in the UK - Guidance for UK higher education providers. http://www.qaa.ac.uk/Publications/InformationAndGuidance/Pages/International -students-studying-in-the-UK.aspx (accessed December 1, 2013).

Quinn, B., and A.M. Doherty. 2000. Power and control in international retail franchising - evidence from theory and practice. International Marketing Review 17 (4/5): 354-372.

Raimo, V. 2013. Agents-The business case for an ethical approach. World University News March 16, accessed 18 March, 2014. http://www.universityworldnews.com /article.php?story=20130312164957652

Reisberg, L., and P. G. Altbach. 2011. The Ambiguities of Working with Third-Party Recruiters. International Higher Education 63: 4-5. https://www.bc.edu/content/dam/files/research_sites/cihe/pdf/IHEpdfs/ihe63.pdf (accessed November 20, 2013)

Reuer, J.J., and R. Ragozzino. 2006. Agency hazards and alliance portfolios. Strategic Management Journal 27 (1): 27-43.

Roberts, P. and K. Dunworth. 2012. Staff and student perceptions of support services for international students in highereducation: a case study. Journal of HigherEducation Policy \& Management 34 (5): 517-528. 
Ross, M., and D. Grace. 2012. Exploring the international student recruitment industry through the Strategic Orientation Performance Model. Journal of Marketing Management 28 (5-6): 522-545.

Scott, P. 1998. The globalization of higher education, 134. Buckingham: Society for Research into Higher Education \& Open University Press.

Shanka, T., V. Quintal, and R. Taylor. 2006. Factors influencing international students' choice of an education destination - A correspondence analysis. Journal of Marketing for Higher Education 15 (2): 31-46.

Sharma, A. 1997. Professional as agent: Knowledge asymmetry in agency exchange. Academy of Management Review 22 (3): 758-798.

Shay, M., J. Molony, and G. Mittal. 2013. Best practices in the use of student recruiting agents by graduate schools and programmes. http://ajcunet.edu/Assets/Conference/File/Best\%20practices\%20in\%20the\%20us e\%20ofstudent\%20recruiting\%20agents\%20by\%20graduate\%20programs.pdf (accessed December 1, 2013).

Smith, K. 2010. Assuring quality in transnational higher education: a matter of collaboration or control? Studies in Higher Education 35 (7): 793-806.

Tadaki, M., and C. Tremewan. 2013. Reimagining internationalization in higher education: international consortia as a transformative space? Studies in Higher Education 38 (3): 367-387.

Tate, W.L., L.M. Ellram, L. Bals, E. Hartmann, and W. van der Valk. 2010. An agency theory perspective on the purchase of marketing services. Industrial Marketing Management 39 (5): 806-819.

Whipple, J.M., and J. Roh. 2010. Agency theory and quality fade in buyer-supplier relationships. International Journal of Logistics Management 21 (3): 338-352.

Wilkinson, I.F. 1996. Distribution channel management: Power considerations. International Journal of Physical Distribution and Logistics Management 26 (5): 31-41.

deWit, H. 2002. Internationalization of Higher Education in the United States of America and Europe: A Historical, Comparative, and Conceptual Analysis. Westport, CT: Greenwood Press.

deWit, H. 2011. Trends, Issues and Challenges in Internationalisation of Higher Education. Amsterdam. Centre for Applied Research on Economics and Management, Hogeschool van Amsterdam. 
Woodall, W., A. Hiller, and S. Resnick. 2014. Making sense of higher education: students as consumers and the value of the university experience, Studies in Higher Education 39 (1): 48-67.

Yen, D.A., H.P.S. Yang, and B. Cappellini. 2012. Ranking gives power: Relationships between uk universities and Chinese agents. Journal of General Management 38 (1): 23-44.

Yin, R.K. 2009. Case study research: Design and methods. $4^{\text {th }}$ ed. London: Sage.

Zhang, Y., and S. Hagedorn. 2011. College application with or without assistance of an education agent: experience of international Chinese undergraduates in the US. Journal of College Admission 212 (summer): 6-16.

Zhuang, G., and X. Zhang. 2011. Impact of relationship marketing orientation on the exercise of interfirm power and relational governance in marketing channels: Empirical evidence from China. Journal of Marketing Channels 18 (4): 279302.

Zu, X., and K. Hale. 2012. An agency theory perspective on supply chain quality management. International Journal of Operations and Production Management 32 (4): 423-446. 